\title{
Effects of the best combination of copper, zinc, iron, and manganese on the relationship of lettuce resistance to Botrytis cinerea and its antioxidant system
}

\author{
Chengjie Pan, Xiangge Du \\ Research Centre of Organic Agriculture Technology, China Agriculture University, Beijing, China
}

\section{A B S T R A C T}

\begin{abstract}
The aim of this study was to reveal the mechanisms and mutual relationships of the lettuce resistance to Botrytis cinerea under the different combinations treatments of copper, zinc, iron, and manganese compounds. The results of this research confirmed: The copper sulfate $0.16 \mathrm{mg} / \mathrm{L}$, zinc sulfate $0.22 \mathrm{mg} / \mathrm{L}$, EDTA-iron $60 \mathrm{mg} / \mathrm{L}$, and manganese sulfate $3.20 \mathrm{mg} / \mathrm{L}$, were added to a Yamasaki nutrient solution, which lead to the antioxidant capacity of the lettuce leaves became stronger. Following the inoculated-pathogen treatment, the contents of superoxide anion radical $\left(\mathrm{O}_{2} \cdot\right)$, Hydrogen peroxide $\left(\mathrm{H}_{2} \mathrm{O}_{2}\right)$, and malondialdehyde (MDA) in the lettuce leaves were decreased. The superoxide dismutase (SOD) played a dominant role in eliminating the influence of $\mathrm{O}_{2} \cdots$. The elimination of the $\mathrm{H}_{2} \mathrm{O}_{2}$, and the maintenance of a certain level was the combined effect of the catalase (CAT), ascorbate peroxidase (APX), and glutathione peroxidase (GPX), the CAT was the dominant enzyme, the APX and CAT enzymes showed a synergic action, and the GPX and CAT enzymes were complementary. The copper, zinc, iron, and manganese were found to have affected the mechanism of this reaction. Therefore, it was a feasible approach to add the correct amount of metal elements into the Yamasaki nutrient solution, which would potentially improve the resistance of the lettuce to Botrytis cinerea and activate its antioxidant enzymes.
\end{abstract}

Keywords: Metal; Reactive oxygen species; Antioxidant system; Lettuce Botrytis cinerea

\section{INTRODUCTION}

Oxygen is an indispensable material in the life of the plant, and is involved in its metabolism, mitochondrial respiration, oxidative phosphorylation, and energy production. However, oxygen will be activated to become a superoxide anion free radical, hydroxyl radical, hydrogen peroxide, lipid peroxide, and singlet oxygen in these processes, and usually reactive oxygen species (ROS) (Apel et al., 2004; Hancock et al., 2001). Studies have shown that ROS is an important signal molecule in the normal growth of plants. It plays an important role in the development process, and is involved in a plant's intracellular, molecular, biochemical, and physiological responses. In particular, it plays an important role in the processes of a plant's defense responses and programmed cell death (PCD) (Bhattacharjee, 2005; Gruissem et al., 2012). However, cell membranes may suffer peroxidation from their reactive oxygen with extremely strong oxidation, which results in membrane damage, and causes the loss of metabolism function and cell death (Gechev et al., 2005; Ryter et al., 2007).

During the normal growth of plants, the generation and removal of reactive oxygen species is a dynamic equilibrium state. When the production of ROS is greater than the removal, the ROS will be accumulated in the cells, and cause oxidative stress. When the production is too large, it will cause a plant to undergo self-inflicted injuries (Hideg et al., 2002). Under a pathogen infection, it will generate a large amount of ROS. Therefore, the plant will suffer from oxidative stress, which could even cause death. In the main reactive oxygen species, a superoxide anion radical $\mathrm{O}_{2}$ - is a type of medium active short-lived ROS. It is not able to pass through the biological membranes, and can easily be disproportionate to generate $\mathrm{H}_{2} \mathrm{O}_{2}$ (Foreman et al., 2003; Schopfer et al., 2001). The $\mathrm{O}_{2}{ }^{-}$can reduce a

\footnotetext{
${ }^{*}$ Corresponding author:

Xiangge Du, Research Centre of Organic Agriculture Technology, China Agriculture University, Beijing, 100094, China.

Tel: +86-10-62733113. E-mail: duxge@cau.edu.cn
}

Received: 11 July 2016; $\quad$ Revised: 02 February 2017; $\quad$ Accepted: 02 March 2017; Published Online: 13 March 2017 
quinone compound, and transition the metal complexes of $\mathrm{Fe}^{3+}$ and $\mathrm{Cu}^{2+}$, and thereby influence some of the metal enzyme activities. $\mathrm{H}_{2} \mathrm{O}_{2}$ is a type of moderate activity and a long-lived molecular. A certain amount of $\mathrm{H}_{2} \mathrm{O}_{2}$ stimulates the performance of a plant's signal transduction and defense features (Allakhverdiev et al., 2004). However, an excessive accumulation of $\mathrm{H}_{2} \mathrm{O}_{2}$ will cause damage to a plant(Neill et al., 2002).

Therefore, the ROS accumulation in plants must be strictly controlled. During long-term evolution, the plant itself forms an antioxidant defense system, and effectively controls the level of ROS in vivo, including antioxidant enzyme and non-enzymatic systems (Apel et al., 2004; Sharma et al., 2007). The main enzymes in a plant's antioxidant enzyme system include SOD, CAT, APX, and GPX (Foyer et al., 2005). The pathogen induced receptor $(\mathrm{R})$ signal acts on the superoxide anion free radical, and is generated by the oxidase in the plasma membrane or non-protoplast. The $\mathrm{O}_{2}$ - has strong toxicity, and may help kill the infected pathogenic bacteria. At the same time, $\mathrm{H}_{2} \mathrm{O}_{2}$ is a second important messenger in the disease resistance responses. The present study has shown that $\mathrm{H}_{2} \mathrm{O}_{2}$ can serve as stress signaling molecules, which induce the SOD, CAT, APX, GPX, and other antioxidant enzyme activities, as well as antioxidant synthase gene expression (Apel et al., 2004; Bewley et al., 1994; Bowler et al., 1991). Therefore, a certain amount of $\mathrm{H}_{2} \mathrm{O}_{2}$ is necessary for the normal performance of a plant's defense.

The sensitivity of plants is different for the different metal elements. Some of the metals are essential elements for plant growth. The structure of antioxidant enzymes also contains the corresponding metal, and the antioxidant process requires the participation of some metal ions as well. Copper, zinc, iron, and manganese are the ingredients of some of the important antioxidant enzymes. For example, copper, zinc, iron, and manganese are components of $\mathrm{Cu} / \mathrm{Zn}-\mathrm{SOD}, \mathrm{Fe}-\mathrm{SOD}$ and Mn-SOD (Mc Cord, 1985; Sandalio et al.,1987); CAT is iron containing hemoglobin enzymes; and APX is a hemoglobin comprised of a peptide chain and an iron containing porphyrin, along with apoprotein molecules binding to the heme in order to constitute the entire enzyme (Mittler et al., 2004). The GPX in plants is usually divided into two categories: selenium containing, and non-selenium containing. They both play an important role in the membrane lipid peroxidation of a plant's defense (Noctor et al., 2002). These metals are important components of the enzyme structure. Some are involved in the expression of the enzyme activity, some are the enzyme activity material, and adequacy and deletion of these metal elements will affect the enzyme activities, and also affect the antioxidant capacity of the enzyme system. The antioxidant enzymes activities are correlated with biological electron transfer processes. Due to the fact that the properties of the transition metals $\mathrm{Cu}, \mathrm{Zn}$, $\mathrm{Fe}, \mathrm{Mn}$ easily gain and lose electrons, these metals are the important external factors which affect the occurrence, transfer, and loss of ROS, as well as the mutual influence and transformation.

Plasma membrane is the main channel of plant cell exchanging with external matter and energy, and also is the most sensitive part for external environmental stress. Damaged plasma membrane and increased membrane permeability are the main essences of disease infection injury. Membrane lipid peroxidation is the primary mechanism for plant damage. Through membrane lipid peroxidation and lipid membrane degreasing processes, MDA may ultimately be formed. Once the membrane system is damaged, the differential permeability will loss, electrolytes, and some small organic molecules may seriously leak, and the balance of exchange in the cellular materials becomes damaged. The distribution and localization pattern of the enzymes in the cells disappear. The order and direction enzymatic reaction experience errors, which may result in metabolic disorders, and even cell death. Therefore, changes in the content of the MDA are often used to reflect the severity of the cell membrane damage by reactive oxygen species (Kuo et al., 2003).

The relationship between parts of the metal elements and disease incidence during plant disease infections can be summarized as the pathogen infection resulting in the increased content of $\mathrm{O}_{2}^{--}, \mathrm{H}_{2} \mathrm{O}_{2}$, and other reactive oxygen species and the membrane lipid peroxidation product MDA in plants. At the same time, the changes of some of the plant antioxidant related metals, such as copper, zinc, iron, and manganese, regulate the activity of the antioxidant enzyme systems, such as SOD, CAT, APX, GPX, and so on, and cause the content changes of the reactive oxygen species and plant peroxidation products, which may eventually affect the plant disease index.

Lettuce Botrytis cinerea is a common disease in the seedling stage, characterized by soaked rotting stems and leaves, which cause immeasurable impact on lettuce production. However, in the early growth stage of lettuce, adjusting the ratios and concentrations of exogenous copper, zinc, iron, and manganese metal elements may improve the synthesis and activities of the enzyme proteins to a certain extent. These adjustments reduce the incidence of the disease, and play an important role in the prevention and control of disease. 


\section{MATERIALS AND METHODS}

\section{Plant material and culture}

In this study, the materials used were Da Su Sheng lettuce seed acquired from the Institute of Vegetables and Flowers, Chinese Academy of Agricultural Sciences. First of all, the seeds were placed in a biological incubator to initiate germination until the cotyledons expanded. The consistent growth of the seedlings were transferred to a floating plate water box, and then cultured in an incubator. The incubation conditions included a daytime temperature of $25^{\circ} \mathrm{C}$, and night temperature of $15^{\circ} \mathrm{C}$. The relative humidity was $70 \%$, and the light intensity during the daytime was $3.6 \mathrm{umol} \cdot \mathrm{m}^{-2} \cdot \mathrm{s}^{-1}$.

A Japan Yamasaki lettuce formulation was used for the lettuce cultivation nutrient solution, with a specific nutrient solution formula (L) as follows: $\mathrm{Ca}\left(\mathrm{NO}_{3}\right)_{2} \cdot 4 \mathrm{H}_{2} \mathrm{O}, 236 \mathrm{mg} ; \mathrm{KNO}_{3}$, $404 \mathrm{mg}$; $\left(\mathrm{NH}_{4}\right)_{2} \mathrm{HPO}_{4}, 57 \mathrm{mg} ; \mathrm{MgSO}_{4} \cdot 7 \mathrm{H}_{2} \mathrm{O}, 123 \mathrm{mg}$; EDTA-2NaFe, $30 \mathrm{mg} ; \mathrm{H}_{3} \mathrm{BO}_{3}, 2.86 \mathrm{mg} ; \mathrm{MnSO}_{4} \cdot 4 \mathrm{H}_{2} \mathrm{O}$, $2.13 \mathrm{mg} ; \mathrm{ZnSO}_{4} \cdot 7 \mathrm{H}_{2} \mathrm{O}, 0.22 \mathrm{mg} ; \mathrm{CuSO}_{4} \cdot 5 \mathrm{H}_{2} \mathrm{O}, 0.08 \mathrm{mg}$; and $\left(\mathrm{NH}_{4}\right)_{6} \mathrm{Mo}_{7} \mathrm{O}_{24} \cdot 4 \mathrm{H}_{2} \mathrm{O}, 0.02 \mathrm{mg}$. First of all, the seedlings were transferred into the water box containing a half nutrient solution, and every two weeks were changed once, twice in total. Then, at the time of the $3^{\text {rd }}$ change, they were transferred into a full nutrient solution, which was changed once a week, for a total of three times. The half nutrient solution contained half the amount of the full nutritional content.

\section{Plant material treatments}

The plant materials were divided into a non-inoculated group (expressed in $\mathrm{N}$ ), and an inoculated (represented by $\mathrm{Y}$ ) group. Both of the groups were cultured in a nutrient solution for seven weeks, and then a certain amount of $\mathrm{CuSO}_{4} \cdot 5 \mathrm{H}_{2} \mathrm{O}, \mathrm{ZnSO}_{4} \cdot 7 \mathrm{H}_{2} \mathrm{O}, \mathrm{EDTA}-\mathrm{FeNa}_{2}$, and $\mathrm{MnSO}_{4} \cdot \mathrm{H}_{2} \mathrm{O}$ were added into the nutrient solution, with concentrations of $0.16 \mathrm{mg} / \mathrm{L}, 0.22 \mathrm{mg} / \mathrm{L}, 60 \mathrm{mg} / \mathrm{L}$, and $3.20 \mathrm{mg} / \mathrm{L}$ (treatment group represented by T), respectively. Then, a group was cultured with a normal Yamasaki lettuce nutrient solution as a control $(\mathrm{CK})$. The specific experimental design is as shown in Table 1.

Three days after the metal treatment, the $\mathrm{Y}$ group received a disposable inoculation of Botrytis cinerea. The lettuce Botrytis cinerea was collected from the field, and cultured in an incubator until its concentration reached $10^{7}$ levels of Botrytis cinerea spore suspension. The leaves of lettuce were sprayed evenly with Botrytis cinerea spore suspension by small watering can, and upper blade simple spraying.

\section{Preparation of the crude enzyme extract of lettuce leaves}

The lettuce leaves at the same position from the different treatment combinations were collected at $0,6,12,24,48$, and 96 hours after the inoculation. Each of the samples was weighed approximately $2 \mathrm{~g}$, and were placed into a mortar on ice. The samples were added to a pre-chilled $6 \mathrm{~mL} 0.01 \mathrm{M}$ phosphate buffer $(\mathrm{pH}=7.4)$ and ground into a pulp. They were then poured into centrifuge tubes, and quickly placed into a centrifuge with $12000 \mathrm{r} / \mathrm{min}$ at $4^{\circ} \mathrm{C}$ for 20 minutes. The supernatant which was obtained were a crude enzyme extract, which was then stored at $-20^{\circ} \mathrm{C}$ for future use.

\section{Determination of the activities of SOD, CAT, APX, and GPX}

The determination of the SOD activity was measured in accordance with the Giannopolitis et al. (1977) method, with certain changes made. A $100 \mu \mathrm{L}$ crude enzyme extract was added, with $2 \mathrm{~mL} 39 \mathrm{mM}$ methionine (Met), $2 \mathrm{~mL} 0.225 \mathrm{mM}$ tetrazolium (NBT), $1 \mathrm{~mL} 0.6 \mathrm{mM}$ of EDTA- $\mathrm{Na}_{2}$, and $1 \mathrm{~mL} 0.012 \mathrm{mM}$ riboflavin, which was then well shaken. A non-enzyme reaction tube served as the maximum photochemical reduction tube. This was placed into an artificial incubator at room temperature for 20 minutes, under fluorescent lights with $72 \mathrm{umol} \cdot \mathrm{m}^{-2} \cdot \mathrm{s}^{-1}$, and finally left in dark conditions to terminate the reaction. The absorbance was measured at $560 \mathrm{~nm}$, and a unit of SOD activity inhibited $50 \%$ of the NBT light. A Moore coefficient with $39.4 \mathrm{mM}^{-1} \mathrm{~cm}^{-1}$ was used to calculate the enzyme activity.

The determination of the CAT activity was measured in accordance with the Kato et al. (1987) method. First of all, $3 \mathrm{~mL} 50 \mathrm{mM}$ of PBS ( $\mathrm{pH}=7.0$ ) was added into a quartz cuvette. Then, $50 \mu \mathrm{L}$ enzyme solution was added, and the solution was well shaken. At this point, $100 \mu \mathrm{L} 2 \%$ of $\mathrm{H}_{2} \mathrm{O}_{2}$ was added, and the solution was again well shaken. An absorbance reading of $240 \mathrm{~nm}$ indicated it was stable. Measurements were taken every 0.5 minutes for each, for a total measurement of three times. A spectrophotometer

Table 1: Experimental design for the different metals and concentrations

\begin{tabular}{lcccc}
\hline Treatment & \multicolumn{3}{c}{ Experimental factors } \\
\cline { 2 - 5 } & $\mathrm{CuSO}_{4} / \mathrm{mgL}^{-1}$ & $\mathrm{ZnSO}_{4} / \mathrm{mgL}^{-1}$ & 30 & 2.13 \\
CKN & 0.08 & 0.22 & 60 & 3.20 \\
TN & 0.16 & 0.22 & 30 & 2.13 \\
CKY & 0.08 & 0.22 & 60 & 3.20
\end{tabular}

CKN: No metals added, non-inoculated; TN: Metals added, non-inoculated; CKY: No metals added, but inoculated; TY: Metals added and inoculated 
was adjusted to zero with $3 \mathrm{~mL} 50 \mathrm{mM}$ of PBS. A unit of CAT activity was the OD value decreased by 0.1 per minute.

The APX activity was measured in accordance with the Nakano et al. (1981) method, with certain changes made. The reaction solution contained $1.6 \mathrm{~mL} 50 \mathrm{mM}$ PBS (pH7.0), $0.3 \mathrm{ml} 1 \mathrm{mM}$ EDTA-Na $2,0.3 \mathrm{~mL} 5 \mathrm{mM}$ ascorbate (ASA), and $0.3 \mathrm{~mL}$ of deionized water. Then, the cuvette was placed into a spectrophotometer, and $0.3 \mathrm{~mL} 1 \mathrm{mM}$ of $\mathrm{H}_{2} \mathrm{O}_{2}$ was added to start the reaction. A reading absorbance at $290 \mathrm{~nm}$ every 10 seconds, measured for 1 minute, and the amount of oxidation of 1 umol ASA enzyme per minute serve was a unit $\mathrm{U}$. The absorption coefficient was $2.8 \mathrm{mM}^{-1} \mathrm{~cm}^{-1}$ for the calculation of the enzyme activity.

The determination of the GPX activity was in accordance with the Navrot et al. (2007) method, with certain modifications. The preparation of the reaction system, a total of $2.4 \mathrm{~mL}$ with $1 \mathrm{mM}$ reduced glutathione $(\mathrm{GSH})$, $0.1 \mathrm{mM}$ NADPH, $2 \mathrm{mM}$ sodium azide, and $0.5 \mathrm{u} / \mathrm{mL}$ GRT, $1 \mathrm{mM}$ EDTA. Each of the reaction systems was added into the $0.3 \mathrm{~mL}$ enzyme solution, which was reacted for 6 minutes, followed by the addition of $0.3 \mathrm{~mL}$ of hydrogen peroxide, measured rapidly at $340 \mathrm{~nm}$, measured once every 20 seconds, for a total of 3 times. The extinction coefficient of GPX measurement was $6.22 \mathrm{mM}^{-1} \mathrm{~cm}^{-1}$.

\section{Determination of $\mathrm{O}_{2}-\mathrm{H}_{2} \mathrm{O}_{2}$, and MDA content}

The determination of the $\mathrm{O}_{2}$ content was made using an XTT (2, 3-bis (2-methoxy-4-nitro-5-sulphenyl) $(2 \mathrm{H})$ tetrazolium-5-carboxanilide; 2,3-[1-(phenylcarbamoyl group) -3, 4-tetrazole]- bis (4-methoxy-6-nitro) benzene sulfonate) method (Frahry et al., 2001). A colorimetric reaction solution ( $3 \mathrm{~mL}$ volume in total) containing $0.1 \mathrm{~mL}$ of the crude enzyme extract, and $1 \mathrm{mM} \mathrm{KCl}, 0.1 \mathrm{mM}$ of $\mathrm{CaCl}_{2}, 0.5 \mathrm{mM}$ of the XTT $(2.9 \mathrm{ml}$ volume in total), and the final absorbance was measured at $470 \mathrm{~nm}$.

The determination of the $\mathrm{H}_{2} \mathrm{O}_{2}$ content was according to the Jana et al. (1982) method, with a small modification. $1 \mathrm{~mL}$ of the lettuce leaf crude enzyme extract under different treatments was extracted, and $1 \mathrm{~mL} 0.1 \%$ titanous sulfate was added $\left(\mathrm{Ti}\left(\mathrm{SO}_{4}\right)_{2}\right.$ with $20 \%$ sulfuric acid $\left(\mathrm{H}_{2} \mathrm{SO}_{4}\right)$ dissolved). This solution was then allowed to stand for 10 minutes, and centrifuged again at $6000 \mathrm{~g}$ for 15 minutes. The absorbance was measured at $410 \mathrm{~nm}$. The absorption coefficient of the $\mathrm{H}_{2} \mathrm{O}_{2}$ content was $0.28 \mathrm{umol}^{-1} \mathrm{~cm}^{-1}$.

The determination of malondialdehyde (MDA) adopted a thiobarbituric acid method (Cakmak et al., 1991), and a crude enzyme extract was added with a $4 \mathrm{~mL} 0.5 \%$ of thiobarbituric acid (dissolved in 20\% trichloroacetic acid) solution. This was shaken well, and heated at $95^{\circ} \mathrm{C}$ for
15 minutes. It then was centrifuged at $3000 \mathrm{~g}$ for 15 minutes after rapid cooling. The absorbance values were measured at $\mathrm{OD}_{532}, \mathrm{OD}_{600}$, and $\mathrm{OD}_{450}$ using a supernatant, respectively. The MDA concentration was calculated according to the formula of the MDA concentration: $(\mathrm{uM})=6.45^{*}\left(\mathrm{OD}_{532^{-}}\right.$ $\left.\mathrm{OD}_{600}\right)-0.56 \mathrm{OD}_{450}, \mathrm{MDA}$ content $=\mathrm{MDA}$ concentration $(\mathrm{uM}) *$ extract volume $(\mathrm{ml}) /($ sample weight $(\mathrm{g}) * 1000)$.

\section{RESULTS}

\section{Different metal elements influenced the occurrence degree of the lettuce Botrytis cinerea}

During the inoculation of the group of lettuce, the disease index of the different metal elements ratio was 24.7 , which was significantly lower than the control group (the disease index in the control group was 58.9). It decreased by $34.2 \%$ compared with the control group, and the two groups displayed significant differences. The different metal elements had a good inhibitory effect on the lettuce Botrytis cinerea, and the control effect in the treatment group reached $58.1 \%$.

\section{Effects of the different metal treatments on lettuce $\mathrm{O}_{2} \cdot \mathrm{H}_{2} \mathrm{O}_{2}$, and MDA}

After the first inoculation at 6,12, 24, 48 and 96 hours, respectively, two types of mainly reactive oxygen $\left(\mathrm{O}_{2}-\right.$, $\mathrm{H}_{2} \mathrm{O}_{2}$ ) and MDA in the lettuce leaves were determined. Through the accumulative amounts of the measured values of the three oxidation products under more than five periods showed that the production of $\mathrm{O}_{2}-\mathrm{H}_{2} \mathrm{O}_{2}$, and MDA in the lettuce leaves had been reduced by different degrees in these combinations of metals treatments. Under the conditions of a pathogen infection, compared with the control, the rates of the three types of oxidation products were reduced by $42.85 \%, 5.56 \%$, and $21.29 \%$, respectively (Table 2). Therefore, the combination of the metals after treatment significantly enhanced the antioxidant capacity in the lettuce resistance effects.

\section{Relationship between the radical $\mathrm{O}_{2} \cdot$ of the superoxide anion and its resistance enzymes of SOD}

As shown in Fig.1A, the changes in the overall activity of the SOD in the leaves of the lettuce were relatively stable during the treatments of certain metal compounds, and the fluctuations in the inoculation group were approximately $41.24 \mathrm{U}$. The fluctuation of the control group was approximately $44.80 \mathrm{U}$. The SOD activity in the leaves after inoculation was generally lower than the control group, and reached a minimum value in 6 hours. The SOD enzyme activity recovered to a similar condition of non-inoculation in 72 hours, which illustrated that the synthesis and activity of the SOD enzyme suffered from damage during the period of the Botrytis cinerea infection, and thereby the enzyme activity was inhibited. 
Pan and Du: Effects of metals combination to lettuce diseases

Table 2: Effects of the different metal treatments on the contents of $\mathrm{O}_{2 .-}, \mathrm{H}_{2} \mathrm{O}_{2}$, and MDA

\begin{tabular}{lccccccc}
\hline Inoculation time $(\mathbf{h})$ & $\mathbf{6}$ & $\mathbf{1 2}$ & $\mathbf{2 4}$ & $\mathbf{4 8}$ & $\mathbf{9 6}$ & Cumulant & Reduction rate (\%) \\
\hline $\mathrm{O}_{2} \mathbf{-}^{-}$ & & & & & & & \\
$\mathrm{CKY}$ & 0.193 & 0.900 & 0.664 & 0.707 & 1.045 & 3.510 & \\
$\mathrm{TY}$ & 0.177 & 0.797 & 0.418 & 0.341 & 0.263 & 1.995 & \\
$\mathrm{H}_{2} \mathrm{O}_{2}$ & & & & & & & \\
$\mathrm{CKY}$ & 0.342 & 0.318 & 0.389 & 0.354 & 0.411 & 1.814 & \\
$\mathrm{TY}$ & 0.344 & 0.249 & 0.450 & 0.404 & 0.269 & 1.716 & \\
$\mathrm{MDA}$ & & & & & & & \\
$\mathrm{CKY}$ & 1.935 & 3.540 & 2.561 & 4.196 & 3.401 & 15.633 & \\
$\mathrm{TY}$ & 2.670 & 3.078 & 2.244 & 2.109 & 2.204 & 12.305 & \\
\hline
\end{tabular}

CKY: No metals added but inoculated; TY: Metals added and inoculated, values represent means $\pm S E(n=3)$

During the 0 - to 6-hour period after the inoculation, the activity of the SOD decreased in the leaves, which indicated that the stimulation of Botrytis cinerea inhibited the enzyme synthesis for a short period of time, and then continued to rise. This indicated that the defense mechanism of the lettuce had been triggered, and activated a synthesis of the SOD enzyme for further resistance to the infection of the Botrytis cinerea.

As shown in Fig.2A, during the metal processing in the 0 - to 6-hour period at the early stage of inoculation, the content of $\mathrm{O}_{2}{ }^{-}$began to decrease, then increased dramatically during the 6-to 12-hour timeframe, and finally reached the highest level at 12 hours after inoculation. This was due to the fact that the initial activity of the SOD enzyme began to play a role in the clearance of $\mathrm{O}_{2}{ }^{-}$at the early stage of the inoculation. However, as the pathogen infected and increased, it limited the production and activity of the SOD enzyme, and the content of $\mathrm{O}_{2}$ - increased to the highest level at 12 hours after inoculation. The SOD activity rose after 6 hours, and the content of $\mathrm{O}_{2}^{-}$began to decline rapidly after 12 hours, reaching a minimum at 96 hours. The content of $\mathrm{O}_{2}$ - still increased after 24 hours in the control group, which indicated that the metal combination treatments played an important role in the regulation of the SOD activity and the scavenging of the $\mathrm{O}_{2}-$.

Changes between the $\mathrm{H}_{2} \mathrm{O}_{2}$ and its coordination of the resistance enzymes SOD, APX and GPX activities As shown in Fig.1B, the CAT enzyme in the lettuce leaves showed volatility in the inoculation of the groups, as well as in the control group. In the process of scavenging active oxygen, the CAT was a key enzyme for scavenging $\mathrm{H}_{2} \mathrm{O}_{2}$, and usually elevated CAT activity will lead to the decrease of $\mathrm{H}_{2} \mathrm{O}_{2}$ content. In the inoculation conditions, the CAT activity was reduced in the 0 - to 6-hour period, while the $\mathrm{H}_{2} \mathrm{O}_{2}$ content increased. When the excitation of the CAT enzyme activity increased, the CAT activity reached the highest level in the leaves at 12 hours. At the same time, the content of $\mathrm{H}_{2} \mathrm{O}_{2}$ reached the lowest level (Fig.2B), which indicated that the CAT scavenged $\mathrm{H}_{2} \mathrm{O}_{2}$. After 24 hours, the changes in the CAT activity tended to be stable, and its activity recovered to the similar level as non-inoculation at 96 hours. These results indicated that the $\mathrm{H}_{2} \mathrm{O}_{2}$ scavenging mechanism in the plants tended to be stable, and the $\mathrm{H}_{2} \mathrm{O}_{2}$ content was maintained at a certain level. However, during the overall 0- to 96-hour period, there was no significant relationship between the CAT and $\mathrm{H}_{2} \mathrm{O}_{2}$. Therefore, it could be concluded that there were other equally important enzymes playing a role in the scavenging of the $\mathrm{H}_{2} \mathrm{O}_{2}$.

As shown in Fig.1C, the APX enzyme activity in the leaves under inoculated conditions was higher than that of the control group, which indicated that pathogens activated the activity of the APX. Similar to the CAT enzyme, the main function of the APX enzyme is to eliminate the excessive free radicals of $\mathrm{H}_{2} \mathrm{O}_{2}$ under the premise of substrates in the ASA. The CAT can remove the $\mathrm{H}_{2} \mathrm{O}_{2}$ with higher efficiency, but the affinity of the CAT with the substrate $\mathrm{H}_{2} \mathrm{O}_{2}$ is relatively low. Therefore, other enzymes other than CAT are also needed to remove the $\mathrm{H}_{2} \mathrm{O}_{2}$. The CAT and APX coordinated and interacted, and both are able to work together as the superposition of the CAT and APX, thereby jointly promoting the elimination of $\mathrm{H}_{2} \mathrm{O}_{2}$. Also, these two may also complement each other to eliminate active oxygen, which is related to the plant complex antioxidant environment. In the inoculation conditions, the APX activity appeared at its highest peak at 12 hours after inoculation, while the CAT activity was at its highest value (Fig.1B). This indicated that there was an interaction between these two, and made the scavenging capacity of the $\mathrm{H}_{2} \mathrm{O}_{2}$ in the plants reach its strongest level, and the content of $\mathrm{H}_{2} \mathrm{O}_{2}$ was at its lowest level (Fig. 2B).

As shown in Fig.1D, strong fluctuations for the GPX activity appeared at 24 hours after the inoculation in the leaves, and the enzyme activity was steady during the other times of inoculation and non-inoculation conditions. This was due to the fact that the plants' GPXs were not constitutively expressed. Usually the expression level of the GPX is very low in non-stress conditions. Only a pathogen infection can cause the stress and induced GPX activity, and further accelerate its expression. The GPX is usually considered as the last defense line for the removal 


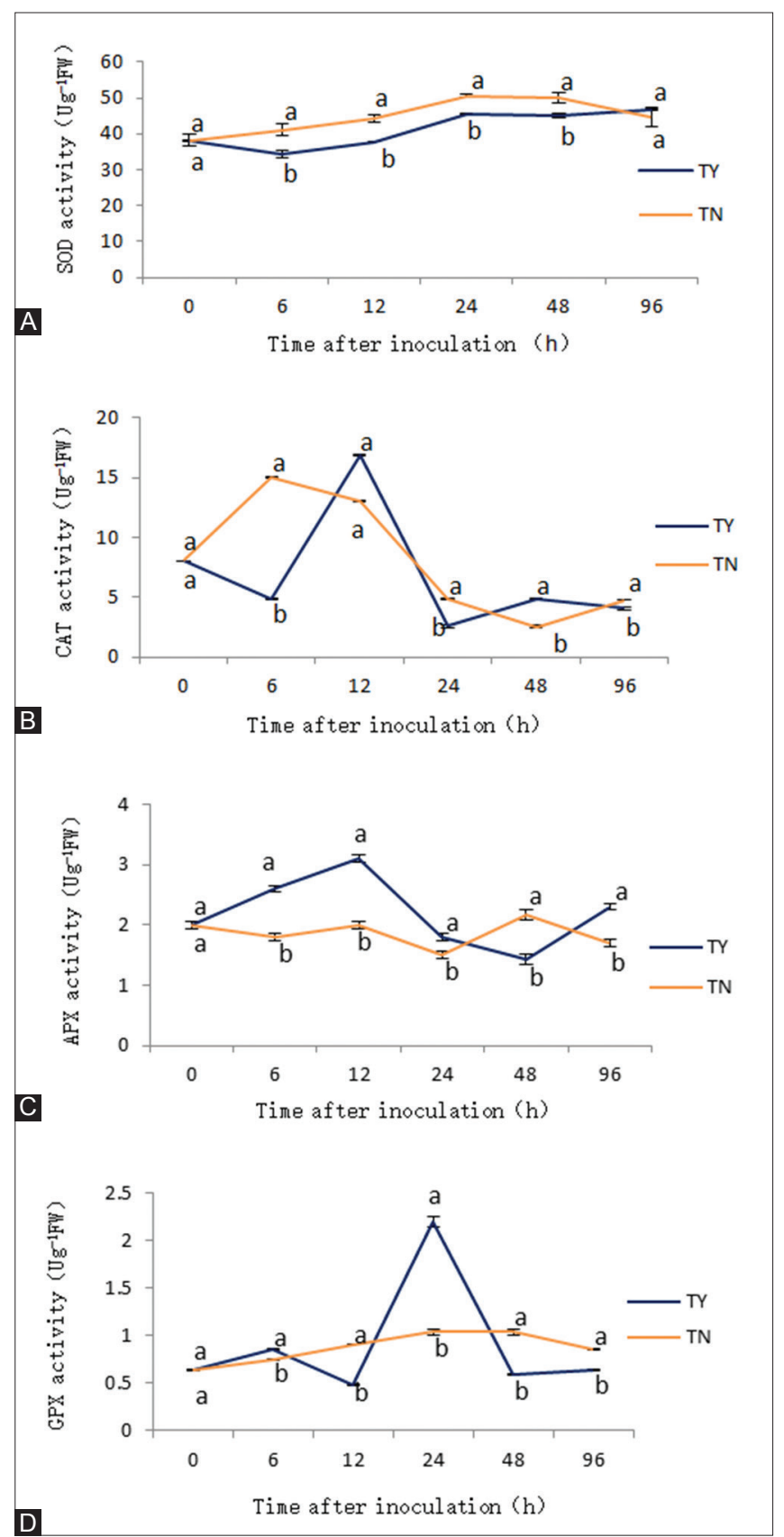

Fig 1. Changes in the SOD (A), CAT (B), APX (C), and GPX (D) activities in the lettuce leaves, within 0- to 96-hour, under metals added. Treatments are as specified in Table 1. TY: Metals added and inoculated; TN: Metals added and non-inoculated. Values represent means $\pm S E(n=3)$, means within a column with different letters are significantly different $(p<0.05)$, means within a column with the same letters are no significant difference $(p>0.05)$.

of $\mathrm{H}_{2} \mathrm{O}_{2}$, and plays a major role when the CAT and APX are not active. When the activity of the CAT was at the lowest level at 24 hours under the inoculation conditions (Fig.1B), the activity of the APX was at a low level as well (Fig.1C). While the activity of the GPX was at a relatively high level, at the same time the content of $\mathrm{H}_{2} \mathrm{O}_{2}$ was still at a relatively stable level (Fig.2B). These results indicated that when the CAT and APX activity was at a lower level,

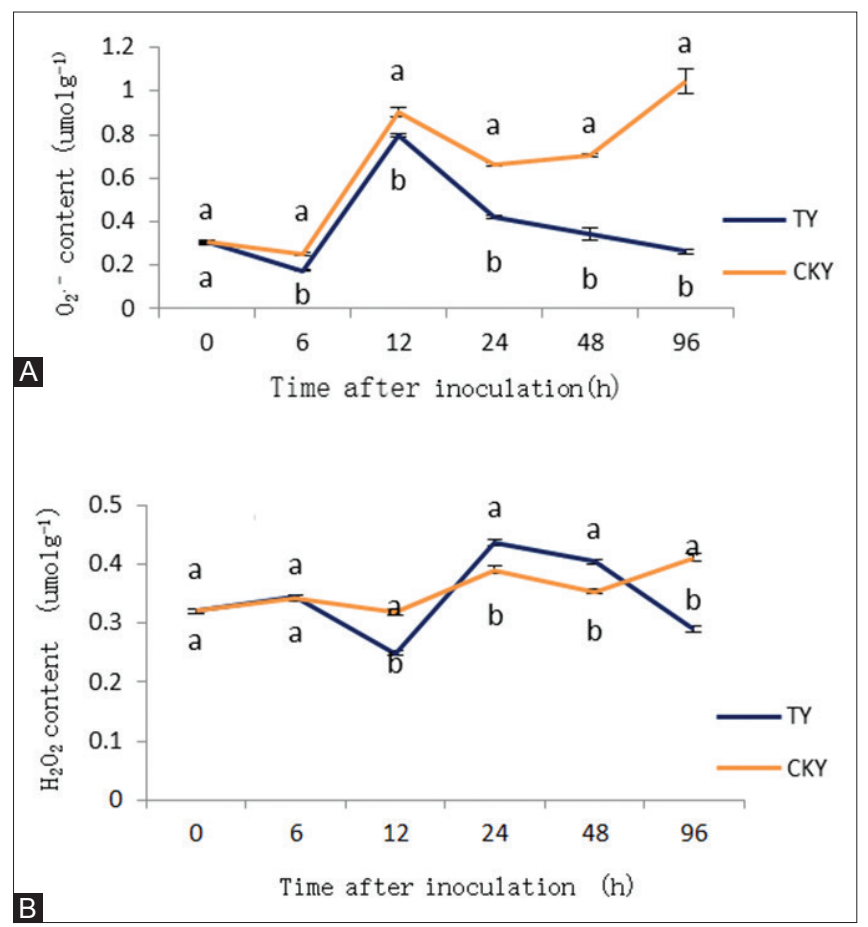

Fig 2. Changes of $\mathrm{O}_{2} \cdot-(A)$ and $\mathrm{H}_{2} \mathrm{O}_{2}(\mathrm{~B})$ content in the lettuce leaves under Botrytis cinerea infection within 0- to 96- hour. TY: Metals added and inoculated; CKY: No metals added but inoculated. Treatments are as specified in Table 1. Values represent means $\pm S E(n=3)$, means within a column with different letters are significantly different $(p<0.05)$, means within a column with the same letters are no significant difference $(p>0.05)$.

the pathogen infection induced the GPX, and played a maximum function in the clearing of the $\mathrm{H}_{2} \mathrm{O}_{2}$. The GPX coordinated with the CAT and APX to keep the content of the $\mathrm{H}_{2} \mathrm{O}_{2}$ in a steady level in the plants.

Correlation analysis between the changes in the $\mathrm{H}_{2} \mathrm{O}_{2}$ and the three enzymes related with $\mathrm{H}_{2} \mathrm{O}_{2}$ scavenging In the metal combination treatment under the inoculated conditions, a correlation analysis of the changes in the CAT, APX, GPX, and $\mathrm{H}_{2} \mathrm{O}_{2}$ within the 0 - to 96-hour period was conducted, and the correlation coefficients were calculated, as shown in Table 3.

As shown in Table 3, the changes of the CAT and $\mathrm{H}_{2} \mathrm{O}_{2}$ were all negatively correlated. That is to say, the rise of the CAT activity resulted in the decrease of the $\mathrm{H}_{2} \mathrm{O}_{2}$ level, and there was a high correlation with $\mathrm{H}_{2} \mathrm{O}_{2}$, which indicated that the CAT was a key enzyme in the inhibition of the $\mathrm{H}_{2} \mathrm{O}_{2}$. The APX was negatively related to the changes in the $\mathrm{H}_{2} \mathrm{O}_{2}$, with high level APX activity leading to the $\mathrm{H}_{2} \mathrm{O}_{2}$ content decreasing significantly. There was a positive correlation observed between the GPX and $\mathrm{H}_{2} \mathrm{O}_{2}$. When the GPX level was high, the $\mathrm{H}_{2} \mathrm{O}_{2}$ level was also high, and when the content of the $\mathrm{H}_{2} \mathrm{O}_{2}$ was high, the activity of the GPX was also high. In other words, only the $\mathrm{H}_{2} \mathrm{O}_{2}$ at a high level can induce the increased of GPX activity, in order 
Table 3: Correlation coefficient of the CAT, APX, and GPX activity, and changes in the $\mathrm{H}_{2} \mathrm{O}_{2}$

\begin{tabular}{lcccc} 
& $\mathrm{H}_{2} \mathrm{O}_{2}$ & CAT & APX & GPX \\
\hline $\mathrm{H}_{2} \mathrm{O}_{2}$ & 1 & & & \\
CAT & -0.87 & 1 & & \\
APX & -0.78 & 0.73 & 1 & \\
GPX & 0.71 & -0.60 & -0.33 & 1 \\
\hline
\end{tabular}

The correlation coefficients were calculated by Karl Pearson's method, the original dates were from table 2

to remove the excess $\mathrm{H}_{2} \mathrm{O}_{2}$. There was also a significantly positive correlation observed between the CAT and APX, as both were elevated at the same time. Therefore, these two had a good synergistic effect. The CAT was significantly negatively correlated with the GPX, and while the level of the CAT was low, the GPX level was high. Therefore, they were mutually complementary. The APX and GPX were negative correlated, and the APX and GPX were low. Therefore, both had a certain complementary effect.

The SOD, CAT, APX, and GPX are antioxidant enzymes, which are directly related to the active oxygen scavenging. The SOD is the first defense line of $\mathrm{O}_{2}$ - scavenging, while the CAT, APX, and GPX are related to the scavenging of the $\mathrm{H}_{2} \mathrm{O}_{2}$ free radical. The CAT is the key enzyme of $\mathrm{H}_{2} \mathrm{O}_{2}$ scavenging, and the APX and CAT have a synergistic effect. The GPX and CAT showed a complementary effect, and the three types of enzyme played synergistic and complementary roles in different ways in order to regulate the content of the $\mathrm{H}_{2} \mathrm{O}_{2}$. The final content of $\mathrm{H}_{2} \mathrm{O}_{2}$ in the plants in this study reached a reasonable level which was beneficial for the plants.

\section{DISCUSSION}

$\mathrm{Cu}$ is one of the trace elements essential for plant growth and development, and is involved in a variety of biochemical and physiological processes of a plant. However, excessive $\mathrm{Cu}$ may produce toxic effects on the plant cells, leading to cell death (Gupta et al.,1999; Wang et al., 2004). The content of copper sulfate in this treatment combination increased above regular levels. However, the active oxygen directly or indirectly induced content decreased when compared with the control group (Table 2). These results indicated that it did not destroy the antioxidant system of the normal body, but resulted in an increase of membrane permeability and biological enzyme inactivation. The plant cells formed a system to scavenge the excess ROS induced by the abiotic and biotic stresses in the long-term evolution, including the non-enzyme and enzyme systems composed of the SOD, CAT, APX, GPX, and other antioxidant enzymes. In the enzyme activity in the leaves of the lettuce under stimulation by botrytis cinerea, the SOD activity had no significant change, and the activities of the CAT and GPX first increased, and then decreased. However, the APX activity increased gradually (Fig.1). The $\mathrm{Cu}$ treatment was able to activate the antioxidant system in leaves of the lettuce, and antioxidant enzymes were able to clear the $\mathrm{Cu}$ induced superoxide anion and $\mathrm{H}_{2} \mathrm{O}_{2}$. In addition, the $0.16 \mathrm{mg} / \mathrm{L} \mathrm{Cu}$ metal in the test did not lead to an increased level of $\mathrm{OH} \cdot$, which had a strong oxidation in the cells. Therefore, it did not successfully induce the membrane lipid peroxidation, or produce less MDA than the control (Table 2). Instead, it played a protective role for the lettuce.

The SOD is the key enzyme of plant antioxidant, as the first anti-oxidase in the active oxygen scavenging system, and it is a ubiquitous metal enzyme in the cells. According to the classes of the binding of metal ions, this enzyme was divided into the three categories of $\mathrm{Cu} / \mathrm{Zn}-\mathrm{SOD}, \mathrm{Fe}-\mathrm{SOD}$, and Mn-SOD. The metal content of zinc in this treatment combination was consistent with the control. However, the SOD activity of the leaves was relatively high, which indicated that the SOD binding ability of the $\mathrm{Cu}$ was better than the $\mathrm{Zn}$, and zinc content was kept at a standard value.

In the long evolutionary process, due to the differences in the growth environments, a plant establishes different efficient iron absorption mechanisms, in order to ensure access to adequate amounts of iron from the soil, and to maintain the growth of plants and the survival of the species. The metal iron content in this treatment combination was doubled based on the standard value. Iron has many antioxidant cofactor components or activators, and is involved in the resistance responses of plants. Therefore, the SOD, CAT, APX, and GPX activity was normally higher than the basic nutritional formula. The high concentration of iron ion led to an oxidation reaction, and whether in the chloroplasts or mitochondria, iron is important in the electron transfer chain. An iron deficiency can lead to blocked electron transfer, which results in excessive reactive oxygen levels. The APX and CAT are important enzymes for scavenging $\mathrm{H}_{2} \mathrm{O}_{2}$ in plants, and have a synergistic effect with SOD in plant antioxidant, thereby protecting plants from excessive ROS damage. Due to the fact that these two enzymes are heme containing enzymes (Kampfenkel et al., 1995; Shigeoka et al., 2002), they are easily influenced by iron stress. The iron deficiency caused the activity of the CAT, and the APX decreased significantly (Ituthe-omaetxe et al., 1995). This study's results showed that in the case of relatively abundant iron, the enzyme activity increased, which indicated that the APX and CAT played effective roles in the scavenging of the $\mathrm{H}_{2} \mathrm{O}_{2}$.

The high Mn stress induced oxidative stress, which may have been one of the reasons for the toxicity. Mn stress can lead to the production of a large number of reactive oxygen radicals in plants. However, the content of active 
oxygen in the leaves in the metal treatment combinations of this experiment was low. Therefore, it could be concluded that a $3.20 \mathrm{mg} / \mathrm{L}$ concentration of $\mathrm{Mn}$ is conducive to promote the removal of reactive oxygen species in plants. In regards to the effects of high $\mathrm{Mn}$ stress on the activity of the CAT, the results were not consistent. For example, a high $\mathrm{Mn}$ stress increased the activity of the CAT in round leaf mint and barley (Demirevska-Kepova et al., 2004), but the CAT activity did not change in tobacco. Meanwhile, Bueno et al.(2002) found that high Mn stress decreased the activity of the CAT in tobacco cells. In this study of lettuce, it was found that the high concentration of $\mathrm{Mn}$ substantially decreased the CAT activity before inoculation, but under abiotic stress, the activity of the CAT increased at 12 hours after inoculation, and then significantly decreased.

This experiment proved that it is a complex process for plants to scavenge ROS and improve disease resistance. The appropriate adjustment of the ratio and concentration of copper, zinc, iron, manganese, and other metal elements, which play important roles in the antioxidant system in plants, could change the function of plant antioxidant enzymes and substances, causing the production and removal of ROS in plants. There is always a metal combination which can effectively reduce the damage of external stress, including the plant pathogens, resulting in a decline in the incidence and index of diseases in plants.

With deepening research, the oxidation resistance of plants has been improved through the use of antioxidants. However, in organic farming, the improvement of plant antioxidant capacity by metal ratio requires more studies. The effective defense against biological stress effects on growth is an important issue. This study found a relatively good formula, which can improve the lettuce's defense against Botrytis cinerea. However, further study is needed to elucidate how these four types of metal ions regulate the antioxidant system, as well as how they interact with each other in the system, and the results must be verified on the molecular level.

\section{ACKNOWLEDGMENT}

We thank R.Y.Tang, F.Wang, W.M.Ding and L.J.Xu for assist the experiment and data analysis, H.Y.Yu and H.Xu for constructive comments on an earlier version of the manuscript.

\section{Author's contributions}

Chengjie Pan performed experiment, analyzed dates and wrote the manuscript. Xiangge Du designed experiment, analyzed result and revised the manuscript.

\section{REFERENCES}

Allakhverdiev, S. I. and N. Murata. 2004. Environmental stress inhibits the synthesis de novo of proteins involved in the photodamagerepair cycle of photosystem II in Synechocystis sp. PCC 6803. Biochim. Biophys. Acta. 1657: 23-32.

Apel, K. and H. Hirt. 2004. Reactive oxygen species: Metabolism, oxidative stress and signal transduction. Annu. Rev. Plant Biol. 55: 373-399.

Bewley, J. D. and M. Black. 1994. Seeds: Physiology and Germination. Plenum Press, New York, p. 445.

Bhattacharjee, S. 2005. Reactive oxygen species and oxidative burst: Roles in stress, senescence and signal transduction in plants. Curr. Sci. 89(7): 0003-1121.

Bowler, C., L. Slooten, S. Vandenbranden, R. de Rycke, J. Botterman, C. Sybesma, M. van Montagu and D. Inzé. 1991. Manganese superoxide dismutase can reduce cellular damage mediated by oxygen radicals in transgenic plants. EMBO J. 10: 1723-1732.

Bueno, P. and A. Piqueras. 2002. Effect of transition metals on stress, lipid peroxidation and antioxidant enzyme activities in tobacco cell cultures. Plant Growth Regul. 36: 161-167.

Cakmak, I. and W. J. Horst. 1991. Effect of aluminum on lipid peroxidation, superoxidate dismutase, catalase and peroxidase activities in root tips of soybean (Glycine max). Physiol. Plant. 83: 463-468.

Demirevska-Kepova, K., L. Simova-Stoilova, Z. Stoyanova, R. Holzer and U. Feller. 2004. Biochemical changes in barley plants after excessive supply of copper and manganese. Environ. Exp. Bot. 52: 253-266.

Foreman, J., V. Demidchik, J. H. F. Bothwell, P. Mylona, H. Miedema, M. A. Torres, P. Linst, S. Costa, J. D. G. Jones, J. M. Davies and L. Dolan. 2003. Reactive oxygen species produced by NADPH oxidase regulate plant cell growth. Nature. 422: 442-446.

Foyer, C. H. and G. Noctor. 2005. Oxidant and antioxidant signaling in plants: A re-evaluation of the concept of oxidative stress in a physiological context. Plant Cell Environ. 28: 1056-1071.

Frahry, G. and P. Schopfer. 2001. NADH-stimulated, cyanideresistant superoxide production in maize coleoptiles analyzed with a tetrazolium-based assay. Planta. 212: 175-183.

Gechev, T. and J. Hille. 2005. Hydrogen peroxide as a signal controlling plant programmed cell death. Cell Biol. 168(1): 17-20.

Giannopolitis, C. N. and S. K. Ries. 1977. Superoxide dismustases occurrence in higher plants. Plant Physiol. 54: 309-314.

Gruissem, W., C. H. Lee, M. Oliver, B. Pogson. 2012. The global plant council: Increasing the impact of plant research to meet global challenges. J. Plant Biol. 55: 343-348.

Gupta, M., A. Cuypers and J. Vangronsveld. 1999. Copper affects the enzymes of the ascorbate-glutathione cycle and its related metabolites in the roots of Phaseolus vulgaris. Physiol. Plant. 106: 262-267.

Hancock, J. T., R. Desikan and S. J. Neill. 2001. Role of reactive oxygen species in cell signaling pathways. Biochem. Soc. 29: 345-350.

Hideg, É., C. Barta, T. Kálai, I. Vass, K. Hideg and K. Asada. 2002. Detection of singlet oxygen and superoxide with fluorescent sensors in leaves under stress by photoinhibition or UV radiation. Plant Cell Physiol. 43: 1154-1164.

Ituthe-ormaetxe, I., J. F. Moran, C. Arrese-Igor, Y. Gogorcena, R. V. Klucar and M. Becana. 1995. Activated oxygen and antioxidant defenses in iron-deficient pea plants. Plant Cell Environ. 18: 421-429. 
Jana, S. and A. Choudhuri. 1982. Glycolate metabolism of three submerged aquatic angiosperms during aging. Aquat. Bot. 12: 345-354.

Kampfenkel, K., M. V. Montagu and D. Inze. 1995. Effects of iron excess on Nicotiana plumbaginifolia plants. Plant Physiol. 107: 725-735.

Kato, M. and S. Shimizu. 1987. Chlorophyll metabolism in higher plants VII. Chlorophyll degradation in senescing tobacco leaves. Phenolic-dependent peroxidative degradation. Can. J. Bot. 65: 729-735.

Kuo, M. C. and C. H. Kao. 2003. Aluminum effects on lipid peroxidation and antioxidative enzyme activities in rice leaves. Bio. Plant. 46: 149-152.

Mc Cord, J. M. 1985. Oxygen-derived free radicals in postischemic tissue injury. N. Engl. J. Med. 312: 159-163.

Mittler, R., S. Vanderauwera and M. Gollery. 2004. Reactive oxygen gene network of plants. Trends Plant Sci. 9(10): 490-498.

Nakano, Y. and K. Asada. 1981. Hydrogen peroxide is scavenged by ascorbate specific peroxidase in spinach chloroplasts. Plant Cell Physiol. 22: 867-880.

Navrot, N., N. Rouhier, E. Gelhaye and J. P. Jacquot. 2007. Reactive oxygen species generation and antioxidant systems in plant mitochondria. Physiol. Plant. 129(1): 185-195.

Neill, S. J., R. Desikan, A. Clarke, R. D. Hurst and J. T. Hancock. 2002. Hydrogen peroxide and nitric oxide as signaling molecules in plants. J. Exp. Bot. 53: 1237-1247.

Noctor, G., L. Gomez, H. Vanacker and C. H. Foyer. 2002. Interactions between biosynthesis, compartmentation and transport in the control of glutathione homeostasis and signaling. J. Exp. Bot. 53: 1283-1304

Ryter, S. W., H. P. Kim, A. Hoetzel, J. W. Park, K. Nakahira, X. Wang and A. M. K. Choi. 2007. Mechanisms of cell death in oxidative stress. Antioxid. Redox. Sign. 9(1): 49-89.

Sandalio, L. M., J. M. Palma and L. A. del Río. 1987. Localization of manganese-superoxide dismutase in peroxisomes isolated from Pisum sativum L. Plant Sci. 51: 1-8.

Schopfer, P., C. Plachy and G. Frahry. 2001. Release of reactive oxygen intermediates (superoxide radicals, hydrogen peroxide and hydroxyl radicals) and peroxidase in germinating radish seeds controlled by light, gibberellin and abscisic acid. Plant Physiol. 125: 1591-1602.

Sharma, P. and R. S. Dubey. 2007. Involvement of oxidative stress and role of antioxidative defense system in growing rice seedling exposed to toxic concentrations of aluminum. Plant Cell Rep. 26: 2027-2038.

Shigeoka, S., T. Ishikawa, M. Tamoi, Y. Miyagawa, T. Takeda and Y. Yabuga. 2002. Regulation and function of ascorbate peroxidase isoenzymes. J. Exp. Bot. 53: 1305-1319.

Wang, S. H., Z. M. Yang, H. Yang, B. Lu, S. Q. Li and Y. P. Lu. 2004. Copper-induced stress and antioxidative responses in roots of Brassica juncea L. Bot. Bull. Acad. Sin. 45: 203-212. 